\title{
El mar no es un paisaje. Introducción a la poesía de Amparo Carballo Blanco
}

\author{
José Enrique MARTÍNEZ FERNÁNDEZ \\ Universidad de León
}

\section{El contexto}

Amparo Carballo Blanco nació en Ponferrada en 1955 y en tal ciudad reside. En mil novecientos cincuenta y cinco España ingresó en la ONU; en el campo literario fue el año de la muerte de Ortega y Gasset y del poeta José Moreno Villa; Gabriel Celaya publicaba Cantos iberos y Blas de Otero, Pido la paz y la palabra. Puede decirse que era el momento de auge de la "poesía social", si bien asomaba en el horizonte una generación nueva, la llamada del 50 o del medio siglo; en efecto, en dicho año cincuenta y cinco aparecían los primeros libros de José Agustín Goytisolo y José Ángel Valente, El retorno y A modo de esperanza, respectivamente. Cuando en 1993 publique Amparo Carballo su primer libro, Tiempos en la misma voz, la situación habrá cambiado de forma absoluta. El franquismo es ya historia, la democracia se ha instalado como forma de gobierno, el Partido Socialista triunfa en las elecciones legislativas y, en el campo de la poesía, contienden diferentes tendencias, si bien premios y apoyos institucionales y críticos parecen coincidir en privilegiar a la llamada "poesía de la experiencia", en la cual caben libros como El hacha y la rosa, de Luis Alberto de Cuenca y Acaso una verdad, de Andrés Trapiello, los dos publicados precisamente en 1993. Tracemos brevemente la pequeña historia.

Hacia 1975 la "estética veneciana" de los novísimos puede darse por terminada, al menos en sus rasgos más sorpresivos (culturalismo y esteticismo, discurso metapoético y actitudes vanguardistas). Los mismos novísimos han evolucionado $\mathrm{y}$, en coincidencia con dicha evolución, aparece una nueva generación de poetas, la que en León representaban los componentes del grupo "Barro", con poetas como Julio Llamazares y Mercedes Castro, entre otros. El cambio producido se podría traducir con el lema "del culturalismo a la vida", lo que significa que remite la exhibición libresca y erudita de los novísimos a favor de una mayor atención al hombre histórico, con lo que ello conlleva de nueva humanización, temporalización de las vivencias y acercamiento al lector común. Tal cambio se produjo como una evolución suave, sin estridencias; no vino acompañada de rechazos violentos ni de proclamas, pero, a la larga, acabó instaurando un nuevo paradigma 


\section{J.E. Martínez Fernández}

estético que traía consigo una concepción diferente de la poesía, nuevos modelos y lecturas y una distinta actitud ante el lenguaje. El cambio no fue obra únicamente de los poetas jóvenes; a él contribuyeron los novísimos mismos y, en general, sus compañeros de generación, cultivaran o no la "estética veneciana" y publicaran temprana o tardíamente. A partir de 1980, aproximadamente, hace su aparición una nueva promoción que no se siente "novísima" ni por edad ni por concepciones y prácticas poéticas. Se trata de poetas como Andrés Trapiello (1953), con Junto al agua (1980), Antonio González-Guerrero (1954), con El peso de mi sombra (1980), José Luis Puerto (1953), con El tiempo que nos teje (1982)... Algunos años después publican su primer libro Justo Navarro (1953), Los nadadores (1985), Margarita Merino (1952), Viaje al interior (1988), Ildefonso Rodríguez (1952), Mantras de Lisboa (1986)... Poetas más jóvenes, como Julio Llamazares, Tomás Sánchez Santiago, Luis García Montero, Felipe Benítez Reyes, Blanca Andreu, Concha García y Juan Carlos Mestre se darán a conocer a fines de los setenta o muy a principios de los ochenta. Sería la promoción a la que, por edad, pertenecería Amparo Carballo Blanco, que, sin embargo, apareció en libro tardíamente: Tiempos en la misma voz se publicó en 1993, cuando la "poesía de la experiencia" es, al parecer, la corriente dominante, sin que ello ahogue otras corrientes fértiles y acaso de mayor rentabilidad futura.

En efecto, durante los últimos veinte años de poesía, a partir de 1985 aproximadamente, la poesía realista, figurativa o de la experiencia resulta ser la corriente mayoritaria por el número de poetas que la cultivan, por la coincidencia de nombres de distintas generaciones y por el impulso que recibe desde diferentes instancias. De esta forma, el campo de la poesía española parece haber quedado dividido en dos grandes parcelas: por un lado, la poesía realista; por otro la poesía experimental. La poesía realista acogería bajo su amplio manto la propiamente llamada poesía de la experiencia (García Montero, Benítez Reyes, Marzal, etc.), la poesía elegíaca (Sánchez Rosillo) y la neoimpresionista (Trapiello). La poesía experimental, de carácter más minoritario, acogería corrientes neosurrealistas y neopuristas fundamentalmente. Tal división responde a dos maneras básicas de entender la poesía: como mímesis o como construcción autónoma. La poesía mimética se acerca a la tradición, la asume y, dentro de ella, elabora sus composiciones en un lenguaje convenido, "hecho", pactado (de ahí el "éxito" social), en busca de la claridad expresiva y del lector complaciente. La poesía experimental, en cambio, respeta la tradición, pero experimenta con ella; el lenguaje es su campo de maniobras; busca el 
sacudimiento de la conciencia y el estímulo de la inteligencia; la realidad no está más allá del poema, que se concibe como universo autónomo y exento; en esta corriente se reconocerían poetas como Miguel Suárez, Olvido García Valdés, Ildefonso Rodríguez o Eloísa Otero.

Entre una y otra parcela circulan otras poéticas de no menor calado, como, por poner algún ejemplo, la que podemos llamar poesía metafísica o trascendente, pues las cosas -y las propias palabras- son únicamente el punto de arranque para trascender hacia más hondos significados (J. L. Puerto, Vicente Valero) y la que podemos denominar "poesía intimista" por su atención preferencial a la propia intimidad, a las emociones propias: en esta corriente se reconoce la poesía de Amparo Carballo.

\section{Poesía intimista}

Nada impide hablar de una corriente intimista dentro de la poesía, a pesar de que el intimismo sea esencial al discurso lírico, al fin un mundo interiorizado y expresado en palabras impregnadas de emoción. Muchas de las cualidades que tradicionalmente se asignan a la lírica (brevedad, intensidad, etc.) responden a las cualidades del intimismo. Comúnmente llamamos intimistas a los poetas que expresan sentimientos interiores, anímicos, personales y delicados; sentimientos como los siguientes: "el cuerpo dolorido / tras batalla de amor, / el corazón huérfano, / la mirada interior, / las líneas de la propia mano" ( $\mathrm{La}$ sombra de las palabras). Es raro que en la obra de un poeta no hallemos parcelas de intimidad versificada, sin entrar ahora en lo que pueda tener o no de ficcional. El "dolorido sentir" ante la destrucción del tiempo y ante la fugacidad de la vida, el desconsuelo ante el desengaño vital, la emoción ante un recuerdo, el ánimo conmovido ante determinadas situaciones..., pueden originar composiciones netamente intimistas; pero quizá ningún sentimiento más íntimo que el amor; ninguna emoción más personal que la amorosa, con toda la estela de motivos que la acompañan, del sufrimiento al gozo, del recuerdo a la esperanza, de la melancolía a la añoranza, del deseo a la posesión. El poema -ha escrito Amparo Carballo- "se nutre de íntimas sustancias" que pueden variar de la luz al abismo, de la plenitud al vacío interior. La poesía late porque anida en el corazón, órgano tradicional de los sentimientos más personales:

Porque el corazón recuerda y murmura como el mar en las caracolas, 
J.E. Martínez Fernández

$$
\begin{aligned}
& \text { conmigo estoy } \\
& \text { y en mi mar me pierdo } \\
& \text { para escuchar el sonido } \\
& \text { del sentimiento. } \\
& \text { (Maleficio de otoño) }
\end{aligned}
$$

De todos los sentimientos ninguno tan cantado por nuestra escritora como el amor: "Es el amor materia / primordial de la poesía", escribe Amparo Carballo en Aletheia, amor que ya en Maleficio de otoño aparecía como origen de la propia poesía:

$$
\begin{aligned}
& \text { Aquí, en pie, caminante } \\
& \text { voy y vengo y voy, } \\
& \text { y cuando } \\
& \text { el amor me sale al paso } \\
& \text { escribo el latido } \\
& \text { en palabras grandes, } \\
& \text { reinvento saltos de luz, } \\
& \text { estreno versos. }
\end{aligned}
$$

Si el amor desaparece, con él se apaga también la poesía:

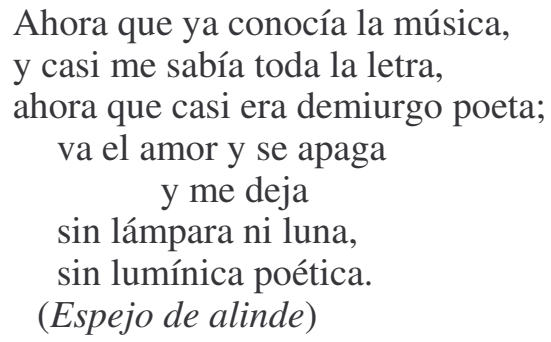

\section{Las obras}

Amparo Carballo ha publicado cinco libros de poemas: Tiempos en la misma voz (1993), Maleficio de otoño (1996), Aletheia (1998), Espejo de alinde (2001) y La sombra de las palabras (2002). Dedicaremos unas breves líneas a cada uno, dejando aparte, por su carácter antológico, Sin otra luz y guía. Poesía, 1993-1998, obra publicada en 1999.

Tiempos en la misma voz aparece en 1993, en plena madurez de la escritora. La palabra emana sinceridad y vigor. Dispone además la autora de una palabra suelta y extensa que recuerda, por poner algunas 
referencias iniciales, la forma de hacer poesía de Neruda o Walt Whitman, por ejemplo. Así lo expresa la escritora: "Ser aprendiz de huracán: Poeta". Por otro lado, si la voz es la misma, como dice el título, no lo son los tiempos, porque en la primera parte del poemario la poetisa vuelve al entendimiento contenidista y utilitario de la poesía social. Así, a un lado está el mundo, el dolor, la ternura, la vida y la muerte; al otro, la poesía, que encadena palabras bellas, soñadoras, emocionantes, como pájaro, nube, alas, sueño, milagro, etc., pero son inútiles por su incapacidad para recoger la vida, evitar la muerte y eliminar la crueldad y la injusticia: "Tan difícil de llevar, / con un verso encendido, / amor, pan y techo / al niño abandonado". Como se ve, reaparece el utillaje léxico de la poesía social: solidaridad, herramienta, trabajo, jornal, sangre, frío, sudor, lucha, esperanza, paz, libertad, etc. La misión del poeta será cantar al y para el hombre corriente, sencillo, "con palabras sencillas y comunes", con "voz humilde y torpe". Pero ese pueblo sencillo, el destinatario natural de esta poesía, vive ajeno a las palabras, sordo, no las escucha: "El pueblo no espera / con las orejas atentas / a los poetas". Al fin, la poesía -como acabaron por entender aquellos poetas- no era un arma para transformar el mundo. De ahí el desencanto final.

En los tres tiempos últimos del poemario la poeta construye un yo más personalizado, que mira hacia dentro más que hacia fuera y que no evita desnudar su intimidad: "Escribo en voz alta / mis arañazos secretos". Y en esa voz alta y desnuda resuena el amor, la melancolía, la ausencia, el recuerdo, el deseo y distintas fragilidades interiores, como el miedo, el dolor, la soledad, etc. Hasta el poema mismo se desnuda de anteriores rémoras y gana en intensidad y brevedad, acaso porque ahora "se nutre de íntimas sustancias". En cualquier caso, los diferentes Tiempos en la misma voz dejan en el lector, -indica Ramón Carnicer en el prólogo- "una impresión profundamente vital", como es propio de una poeta que ha aspirado la vida y nos la devuelve con vehemencia y autenticidad.

Si Tiempos en la misma voz fue el anuncio de un nuevo poeta, Maleficio de otoño es la confirmación de una voz poética. Este segundo libro de la autora, publicado en 1996 y dispuesto en cinco partes, se inicia con una especie de justificación o programa poético. Se trata, antes que nada, de reflexionar sobre lo que uno hace entre temores y esperanzas, dudas y luces: “CCómo decir lo indecible?”, “Cómo liberar el sentimiento / de la palabra misma que lo nombra?". El poeta trabaja, en efecto, con palabras ("no tengo más luz que la luz de la palabra"), que tienen un significado previo, anterior a su uso por el escri- 


\section{J.E. Martínez Fernández}

tor, que debe exprimirlas (y oprimirlas y maltratarlas) para que expresen con nueva fuerza lo que otros han dicho, pero que el poeta quiere decir de nuevo, ansiedad o cansancio, soledad o deseo, amor o silencio, sentimientos que exigen "ser metáfora única / en el verso". De estos sentimientos es el amor en soledad el que destaca, el ansia de amor, "amor de tinta", porque su destino final es el verso teñido de melancolía.

El sentimiento se adueña de tal manera del poemario que, en la segunda parte, el mar, sin que deje de ser una experiencia, opera también como símil del corazón y como espacio simbólico en el que ubicar (salvar, naufragar, navegar) el corazón y el verso, con ricas variaciones en torno a un mismo motivo que intensifica la emoción con que se leen algunos de estos breves poemas verdaderamente conmovedores: "A veces duerme el corazón / sin sentir el embate de las olas, / varado en aguas poco profundas / como simple cascarón, / hasta que sube la marea / y un viento esperanzado llega / desplegando velas, / entonces levo anclas / y dejo que se haga a la mar". El otoño es, en otros casos, el ámbito escogido. Aquí (tercera parte) los árboles se desnudan y el ocre es el color de un otoño que, como antes el mar, se interioriza: "Se mete el otoño en el alma / a dar frío, / y sólo en la rama deshabitada / se acurruca la esperanza"; es el otoño también la estación tradicional de la melancolía, propia de un corazón "sobrecargado de ausencias", para el que (parte cuarta) pedirá piedad, pues contra los sueños atenta el olvido, la sinrazón, la ausencia, el silencio y, sobre todo, el tiempo ("mañana siempre es tarde"), cuya acción acaba adueñándose de la parte última del poemario, en la que el invierno sucede al paisaje otoñal y la nieve que se deshace simboliza el naufragio de los sueños.

Poesía intimista es ésta, en cuanto que el exterior no se canta en su existencia objetiva, sino interiorizado por el sujeto lírico. Lo dice Carnicer en el prólogo: "Lo real y lo soñado se nos muestran bajo las luces y las sombras irradiados de un modo de sentir muy singular, afectado por cuanto desde el amor y el desamor le concierne".

Aletheia, tercer poemario de Amparo Carballo, se publicó en 1998, con prólogo de Antonio Gamoneda y portada y contraportada de José S. Carralero. Gamoneda nos ofrece lo que es en esencia la poesía de Amparo Carballo: sencilla sinceridad, sentimentalidad, suavidad, deseo, melancolía, intimismo, pulsión interior más que artificios externos, confidencialismo tenue, cauce sosegado, serenidad... En fin, una personal voluntad de estilo, con suavidad de formas para una carga semántica pertinente; resume Gamoneda con un símil: "Poemas de 
amor, pues que se posan sobre el silencio de las páginas con la misma cadencia que la sombra de las aves en la quietud de las aguas".

"Es el amor materia / primordial de la poesía". ¿Qué no se habrá escrito sobre el amor! Y, sin embargo, siempre hay algo que añadir; por eso nació Aletheia, con orientación amorosa desde la dedicatoria a alguien que actúa de imán del corazón y de la palabra. La autora del libro poetiza un amor ideal, inalcanzable; sólo la poesía nos permite atisbar la luz más alta hacia la que tiende radicalmente el hombre en busca de la aletheia o verdad oculta bajo velos que la cubren. "Nunca fuiste más real / que cuando fuiste un sueño"; de ahí el deseo de que siga siendo un sueño para que el alma o el corazón soñador viva una plenitud interior sin vaciarse: "Déjame engrandecida / por el anhelo de buscarte". Amor más promesa que fruto, esperanza más que logro, anhelo, en fin, un mar hondo e interminable en el que echar "a navegar el corazón". Que el amor se viva como sueño supone que el despertar sea amargo; de ahí que a veces el amor aparezca como espejismo, encienda nostalgias o suscite esperanzas, tristezas que las palabras no logran ahuyentar, silencios, inconstancias (ese vaivén u oleaje que resuena en muchos versos), pálpitos...

Poesía intimista, sí, de un intimismo leve, suave, tenue..., palabras que le vienen bien a esta poesía que acude, consecuentemente, a formas breves que acogen el temblor de las alas del corazón: vuelo que sugiere el ave, brisa de un viento interior, estela, humo sutil de un fuego que arde dentro, nutrido por los anhelos. A este poetizar aluden muchos de los versos; palabra y amor cumplen una función recíproca, se alimentan mutuamente, pues los une un mismo afán: el de la pervivencia. Poesía intimista, pero cuidadosamente modelada, con artificios que no se notan, contrastes y reiteraciones sobre todo ("ojos sin recato / trampantojos que no engañan, / y se enmarañan / en mis ojos, / y dicen lo que en tus labios callan"). También la poesía tiene algo de juego y la poeta muestra su habilidad en la parte tercera, como enseña su voz más concentrada en los poemas breves de la quinta o como muestra su intenso diálogo intertextual con otras voces (Quevedo, Otero, Neruda, Valente, etc., etc.).

Espejo de alinde fue publicado en el año 2001. El de alinde es un espejo de aumento que, al decir de Cervantes, al que cita la autora, "hace mayores todas las cosas". No me cabe duda de que para la escritora la poesía es espejo de alinde, capaz de dar aumento, fuerza y vigor a lo pequeño. Por otra parte, no es imagen ajena a su obra anterior: el espejo, el cristal, el agua, configuran toda una serie de imágenes, de reflejos persistentes en su poesía. Ya en el "preludio" de este 


\section{J.E. Martínez Fernández}

último libro escribe: "Si pudiera arrancarme / el silencio / como una espina, / y ser como el álamo, / espejo de aire, / cristal de agua en mil hojas / repetida". El espejo multiplica las imágenes repetidamente, como la propia poesía, si hacemos caso a García Márquez que, en cita de la autora, avisa de que la poesía es "energía secreta en la vida cotidiana que cuece los garbanzos en la cocina y contagia el amor y repite las imágenes en los espejos".

Hay en la obra un receptor interno, un tú silencioso, destinatario inicial de las palabras de la poeta: "Yo es frontera de tú"; un tú de desencuentros; un tú y un yo difíciles de descubrir, porque "tú, ¿quién?", y el yo es una búsqueda permanente desde la propia indagación poética. Cuando el tú se generaliza, el desencuentro es también manifiesto: a pesar de avances técnicos de todo tipo cunde el desamor, la dificultad de compartir el pan candeal de la poesía.

La palabra poética es objeto de meditación constante: “¿Cuál es el poder / de la palabra oscura / a plena luz abierta?". No es una pregunta vana. La poeta ha mostrado más de una vez su contrariedad ante la precariedad social de la palabra. Las palabras se manifiestan inútilmente bellas, pues no logran remediar ni la soledad del yo ni las hambres o miserias de los hombres. No es frecuente la referencia social de esta poesía, pero existe una preocupación de tal tenor en algunas composiciones. Definitivamente la poesía no es capaz de cambiar el mundo. A un lado, la miseria y la violencia; al otro, el poeta con sus palabras hermosas e inútiles.

En la primera parte domina la preocupación por el paso del tiempo. Es una preocupación de tipo existencial, con el hombre en el centro, todo él traspasado de tiempo, de fugacidad, como un presente de luz entre dos tinieblas de las que no hay nada que decir, son sólo un antes y un después vacíos. El rubendariano no saber adónde vamos ni de dónde venimos se convierte en la certeza de ser fugitivos, de estar solos, "marineros estancados / en la oscuridad espesa". La imagen manriqueña del río que fluye hacia el mar del morir -citada o recreada- es la que vuelve a dar cuenta de la vida humana en su rápido camino de la vida hacia la muerte, pura inmovilidad no deseada.

En la segunda parte la sustancia temática es el amor, centro originario de la poesía y entrega vital. Reaparecen motivos típicos de la poesía amorosa de siempre: entrega, cercanía y ausencia, recuerdo y deseo, soledades, melancolías...; pero, sobre todo, se canta al amor como ideal inalcanzable, como "inaccesible isla de ensueños". Brota también la imagen tradicional, como aquella que habla de la tierra seca de la amada a la que urge calmar su sed con el agua que es el ama- 
do. Si es difícil ser original en los contenidos de un tema tan traído y llevado por la poesía de todos los tiempos, la misión del poeta es renovar la forma, hacer que lo viejo se presente como nuevo ante nuestros ojos. Amparo Carballo lo hace desde la palabra sencilla y leve, desde el poema breve reducido a lo esencial, al sentimiento desnudo, como en esta bella composición:

$$
\begin{aligned}
& \text { Me he perdido } \\
& \text { porque siento } \\
& \text { que ya no estoy } \\
& \text { sino cuando } \\
& \text { soy contigo. } \\
& \text { Ya no tengo } \\
& \text { más paisaje } \\
& \text { en los ojos, } \\
& \text { ya no encuentro } \\
& \text { más camino. }
\end{aligned}
$$

El mar se convierte (tercera parte) en referente sentimental. No se goza de su infinitud ni de su fuerza, no es un paisaje, es una imagen: el mar de la vida y el mar de la muerte, el mar que permanece frente al hombre pasajero, el mar que inunda de soledad a esa gota de agua que es el hombre, el mar igualitario con su fondo de olvidos, el vaivén de las olas como imagen de la vida reiterativa que pasa y no deja huellas... Y el mar imagen del amor, también sujeto a vaivenes, como las olas, antes de reducirse a espuma, a nada; y la figuración becqueriana de un yo como un mar embravecido frente al tú roca, en inevitable encontronazo, si bien cabe una figuración más amable: "Tú eres el viento / que riza olas y sueños. / Yo agua invadida, sol, sal, la espuma... / El sonido del mar / es nuestro mejor poema". Esta tercera parte termina con un breve poema de tres versos únicamente que resumen un estado de ánimo en torno a tres palabras muy propias de la poesía amorosa: tristeza, ausencia, olvido: “¡Corazón al olvido! / Ausencia a bordo, / honda tristeza a flote".

Llegamos así a la parte final. En ella abundan las composiciones metapoéticas: el poema se convierte en objeto del poema; el poema habla de sí mismo. Reflejan estas composiciones la preocupación de la poeta por su instrumento de trabajo, por la palabra, por el objeto tangible que es el poema y por ese ser abstracto que es la poesía. La composición que comienza "Para que el poema" parece resumir una 


\section{J.E. Martínez Fernández}

manera de entender la poesía y el oficio de poeta: en cuanto a la forma, golpear y acariciar las palabras, es decir, luchar para extraer de ellas la "luz" que guardan; el origen del poema se cifra en el recuerdo y el amor, los dos motivos que sirven de sustento a "la flor de la ilusión"; como cualidades, verdad y misterio, que, a mi parecer, aluden a la autenticidad vital y al halo de sugerencias e intuiciones que acompañan a la palabra poética; como finalidad, y bajo la imagen tradicional del pan compartido, la palabra en comunión, de todos, lo que indica la necesidad del lector, de los lectores, para que la poesía-manjar sea saboreada por todos y alimente en todos aquella "flor de la ilusión". Todo un programa poético.

Si hacemos caso a otras composiciones, la poesía une pensamientos y sentimientos, se forja en el amor, contiene misterio y, entre sus finalidades, está la de "anular turbios venenos". Agua y sed son imágenes que sirvieron al amor y sirven también a la poesía: "Casi todos los días / sufro ataques de sed, / me doy a ti, / y brindo con el agua / de tus fuentes oh, poesía".

No es la poesía, el poema, el único motivo de esta parte final. Reaparecen otros, como el amor o la fugacidad del tiempo, y un elemento de paisaje urbano, la plaza, referente de la soledad, cuando no correlato del corazón vacío.

El poema penúltimo del libro es una justificación del carácter intimista de esta poesía: "Hablo de mí porque soy / el ejemplo que tengo / más a mano, y escribo / contra el olvido". Experiencia personal al fin, mundo interiorizado hecho palabra para salvaguardar la memoria y la emoción.

La sombra de las palabras, de 2002, es, por ahora, el último libro de poemas de Amparo Carballo. "No pases de largo ante la sombra de las palabras"; éstas, de Canetti, le sirven de título a la poeta para su sexta entrega poética si contamos la antología Sin otra luz y guía. Poesía, 1993-1998, obra publicada en 1999. Pero ¿qué sombra es ésa? La poeta nos lo dice en un breve prólogo iluminador, que parte de una verdad primera: "La luz no existe sin la sombra", pero de forma tal que es la sombra la que "crea relieves y resaltes, cambiantes matices y oscuridades más o menos profundas". Se trata de acercarse a lo más profundo de las cosas; sólo el contraste de las sombras "me revelan los contornos y la textura, la luz de las cosas, la realidad auténtica o soñada". Estas palabras habitan, pues, el claroscuro: desde la sombra, revelan el ser de las cosas. Acorde con esta entrada, el libro se divide en tres partes: Sombra, Penumbra, Contraluz. 
Sombra. Las cosas no son sólo luz o sólo sombra. Hay una doble faz: lo vivido y lo soñado entremezclados, lo real y lo ilusorio, la memoria y el olvido. Las palabras mismas pueden decir todo o nada. En el fondo de esta poesía adivino una búsqueda. Buceando entre las sombras, se persigue una verdad, pero con la conciencia previa de que esa verdad no existe. De ahí que exhale una pena íntima, leve, ambigua: melancolía. Parece como si alguna vez se hubiera rozado esa verdad que ha abocado, al fin, a su evanescencia. Adivino también algunos temores: la vida es fluencia y en esa fluencia perdemos siempre; perdemos memoria, perdemos luz, ganamos muerte. Frente a la fluencia, la poesía busca la permanencia; es una lucha contra el olvido, contra sucesivos despojamientos.

Penumbra. La poeta se vuelca sobre la palabra poética. La poesía debería fijar lo fugaz: un resplandor momentáneo, un pájaro volandero; las palabras deberían trazar un límite desde el que comprender el mundo. La palabra debería "congelar su instante [el de las cosas fugitivas] en eterno presente". De ahí que me parezca tan eficaz la imagen de las palabras-redes.

Contraluz. En esta parte última del poemario, la poesía es "un espacio acotado": Amor se llama, con mayúscula, "esa pasión del alma, / explosión primordial / que inventa la plenitud / para alcanzar la nada". Se canta el amor. Sometiéndose a su fuerza, a su poder, a su "divina luz" (ideal), a su "terrible luz" (fuerza). Cuando el amor traspasa el alma del poeta, entonces "estoy en la palabra, vivo". Amor es posesión, ebriedad, totalidad, absoluto, culminación, principio de creación, explosión de la palabra.

La lírica de Amparo Carballo, en breves composiciones, está llena de levedad poética, sugiere, apunta... "Seda hilada con fuego", se expresa en tonos suaves; la palabra acoge el vuelo sencillo, lo tenue, el roce, el aroma: lo sugerente, lo evanescente, lo que casi no es porque se está yendo. De ahí también la leve actitud melancólica, algo que no se nombra, pero que llega al lector en olas menudas, como una caricia, como un roce.

\section{Un mar de imágenes}

Yo sé que el mar no es un paisaje.

Tiene un fondo de olvido benévolo y feroz, oscuro y eterno 
J.E. Martínez Fernández

como la muerte.

En él todas las aguas

se igualan y disuelven

Yo sé que el mar

no es inocente.

(Espejo de alinde)

La escritora cita a Thomas Mann, pues la tercera parte de Espejo de alinde se inicia con estas palabras, a modo de epígrafe, del autor alemán: "El mar no es un paisaje. / Es la expresión de la eternidad, / de la vida y de la muerte: / un sueño metafísico". El mar no es un paisaje, sino un estado de ánimo. Bajo su nombre caben diversas configuraciones imaginativas con diferentes matices. No es el mar la única recurrencia en función "imaginaria" (el espejo es otra destacable), pero sí la más frecuente y fecunda. De forma esporádica aparece ya la imagen del mar en Tiempos en la misma voz: "Adiós, adiós isla / que el mar guarde tu arena..."; "Echo lanzas en el mar / y paseo largas melancolías". La presencia del mar es también ocasional en Aletheia, pero da vida a poemas enteros, algunos muy bellos, como el que comienza: "A mi padre no le gustaba el mar", cuya inmensidad contrasta con otros paisajes pequeños y familiares. Cuando no es mero símil ("Como el mar soy insistente"), el mar puede ser imagen del amor (las olas vienen y van en forma de saludo y despedida o bien como caricia sobre la playa) o referente metafórico de un corazón "abandonado a la deriva": "barco fantasma, / destartalado navío / aprisionado entre hielo".

El mar conforma la imaginería toda de la segunda parte de Maleficio de otoño (veintitrés poemas), de la tercera de Espejo de alinde (veinte poemas) y de algunos poemas de La sombra de las palabras. Olas y vientos, barcos, bateles, veleros, lunas, sirenas y gaviotas, playas, arenas y espumas, soles, peces, caracolas, rocas y acantilados, islas, faros..., todo un paisaje marino que no es paisaje, sino aventura del corazón y la palabra: "En mi mar me pierdo / para escuchar el sonido del sentimiento" (Maleficio de otoño). Salvo en escasos poemas en los que puede percibirse cierta fruición paisajística, el mar funciona básicamente como imagen metafórica de diversos estados de ánimo. De hecho, el mar puede aparecer con sus diferentes atributos (nocturno, inmenso, inmortal), pero acaba siendo interiorizado hasta convertirse en un mar del alma: 
Fluye, refluye y ruge,

mar a mar interior,

tan sin límite

y tan totalmente mío

(Maleficio de otoño)

El mar sirve principalmente como figuración del amor, de la vivencia amorosa, tema esencial en la poesía de Amparo Carballo. Se trata, dice la poeta, de un "mar de amor azaroso", origen de la poesía misma, pues en ese mar imprevisible "se producen los huracanes y los versos" (los huracanes de la pasión amorosa). Como mar azaroso, es movido el barco velero del corazón por vientos favorables o por vientos contrarios. En el caso venturoso, hacerse a la mar es adentrarse en aguas en calma, esperanzadas, o navegar hacia el puerto de salvación o sentirse acariciado por brisas prometedoras:

Vientos favorables impulsan

el velero del verso

en dirección Tú: único puerto,

única isla habitable

en el gélido mar cotidiano

(Maleficio de otoño)

Los vientos contrarios, en cambio, conducen al naufragio amoroso y al consiguiente desengaño, que origina esos poemas en los que "olas y sueños / son lo mismo, / sólo un poco de viento".

Algunas imágenes destacan por su plasticidad:

Caballos desbocados

de crines encendidas

rompen

la tensión superficial

de un hondo mar sin calma.

(Espejo de alinde)

Muy plásticas son también las imágenes que configuran la relación amorosa como batalla entre las rocas y el mar embravecido, a la manera becqueriana en el primer poema que cito ("Tú eras el océano y yo la enhiesta / roca que firme aguarda su vaivén") o como gaviota rota en el segundo: 
J.E. Martínez Fernández

Tú, la sólida roca.

Yo, la mar embravecida.

Allí

donde nos encontramos

en inevitable batalla.

(Espejo de alinde)

Hay una gaviota quieta,

rota junto al mar.

¿Qué ola violenta,

qué golpe de viento,

qué desamor se llevó su vuelo

hacia abismos de olvido?

(La sombra de las palabras)

El poema final de la tercera parte de Espejo de alinde refleja en su brevedad un vacío del corazón navegador por el mar azaroso del amor:

¡Corazón al olvido!

Ausencia a bordo,

honda tristeza a flote.

En Espejo de alinde el mar se convierte en metáfora de la fugacidad temporal del hombre: olas que viene y van eternamente, como imagen de los hombres que pasan sin dejar huella, hasta hundirse en el mar "que es el morir", imagen manriqueña casi inevitable en este caso. Caben, en este sentido, otras posibilidades: el mar, que es el mar del morir, puede ser también "el mar de la vida", con sus vaivenes y naufragios, o configurar una eternidad frente a la que resalta el hombre pasajero, o una inmensidad en la que el hombre es gota de agua ignorada.

La isla, por fin, admite diferentes connotaciones metafóricas o simbólicas. Puede ser refugio amoroso, lugar para el recuerdo... ¿Qué significan los versos "Rodeo mis islas de mar / y sobresaltos de espuma"? ¿Cuáles son las islas del poeta? Las palabras, al parecer, a las que ofrece un "porvenir de arena": "Las palabras son mías / y yo pertenezco / a su porvenir de arena". ¿Qué porvenir es ése? Si hacemos caso a otras composiciones, el poema expresaría el paso por la vida sin dejar huella, porque las huellas en la arena las borran las olas.

Pero la isla es, antes que otra cosa, símbolo de la soledad, de la profunda soledad del hombre, personalizada en este breve poema: 


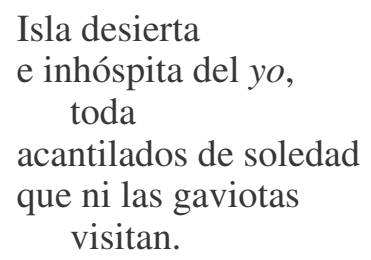

(Espejo de alinde)

\section{Voz de voces}

Para el teórico ruso Mijail Bajtin el ser humano es inconcebible sin el otro, sin las relaciones que con el otro mantiene. En la formación de la conciencia individual, el papel del otro es el de completar la visión de nosotros mismos. Vivir significa dialogar con el otro: es la idea que instaura la naturaleza social del hombre y el llamado principio dialógico. La dialogía establece la relación de palabras propias y ajenas, individuales y colectivas. Frente a la palabra objetual y a la palabra directa, denotativa, autoral, se alza la interacción de voces, la palabra como asunción de la palabra ajena, de la voz del otro. El lenguaje es polifónico por naturaleza. Todo enunciado está habitado por la voz ajena. El lenguaje es una propiedad colectiva y cualquier voz que usemos no ha llegado a nosotros de forma neutra, sino configurada con intuiciones ajenas. Del principio dialógico bajtiniano nació el concepto de intertextualidad; el término y el concepto los forjó Julia Kristeva allá por 1967 y desde entonces han recorrido un largo camino. El vocablo alude a la interacción de voces, al texto entendido como tejido de otras voces; el texto no se legitimaría en su soledad, sino en su relación con otro u otros textos. Esa relación se muestra de manera patente en la cita y en la alusión o evocación de otro texto recordado. En unos y otros casos, el escritor, el poeta, parece sentirse inmerso en una tradición de la que toma préstamos y los vuelve a entregar reelaborados. La poesía de todas las épocas ha atraído hacia el texto poemático concreto textos o microtextos ajenos; así, por ejemplo, versos de Garcilaso servirán de estímulo a Gil Polo, Camoens, Lope de Vega o Góngora. La poesía contemporánea, en sentido amplio, es de una intensa intertextualidad y el hecho ha sido muy estudiado en poetas como Blas de Otero; pero el préstamo (tomado no sólo de la literatura, sino también de las otras voces que nos rodean: refranes, letras de canciones, anuncios, etc.) puede tener funciones muy diferentes: en la poesía social, por ejemplo, sirvió para potenciar el compromiso y ganar al destinatario natural facilitando la referencia intertextual por medio de fragmentos muy presentes en la memo- 


\section{J.E. Martínez Fernández}

ria colectiva del lector español; en cambio, en la poesía novísima (Gimferrer, Carnero, etc.), el préstamo intertextual no busca al lector común, sino al culto y elitista, conocedor de textos exquisitos que al poeta le gusta exhibir. Bien se ve cómo la intertextualidad incluye también al lector. Una cita nunca percibida por nadie es una cita que no existe, a la espera de su activación por lectores futuros; pero, además, la lectura intertextual es una lectura diferente, pues invita a una doble mirada: hacia el texto primero del que procede la cita y hacia el nuevo texto al que la cita, literal o transformada, se ha incorporado. La lectura intertextual es, por así decir, estereofónica.

Cualquiera que se acerque a las obras de Amparo Carballo observará la copiosa intertextualidad de su poesía, un verdadero índice de lecturas que sirven de estímulo inicial en la composición de los textos concretos. Normalmente la escritora facilita la competencias individual con distintas marcas de la cita, como la letra cursiva y la nota a pie de página. Así, si nos fijamos en Aletheia encontramos citas de Aimé Cesaire, Antonio Gamoneda, Francisco Mena Cantero, Jacques Dupin, Blas de Otero, Bécquer, Celso Emilio Ferreiro, Valente, Benedetti, Fray Luis de León, Javier Egea, Antonio Machado, Muñoz Seca, Voltaire, Ángel González, Wislawa Szymborska, Rilke, Emilio Prados, Quevedo, Caballero Bonald y José Antonio Muñoz Rojas. A la vista de la abundancia parece como si todo estuviera ya dicho y el poeta moderno fuera un ser repetitivo. Es una angustia que ha afectado a algunos autores contemporáneos que ven diluirse la identidad del yo en las otras voces, a la que vez que sienten su voz colonizada por las voces ajenas. No es el caso de Amparo Carballo, en cuyos versos domina la fruición de la lectura, el gozo de las voces que ayudan a soportar la soledad, el estímulo de las voces ajenas que sirven para desencadenar la escritura. Lectura y escritura son en ella un mundo único: la lectura incita a escribir; la escritura lleva a nuevas lecturas, en un vaivén fecundo, tanto que algunos poemas concretos no son más que breves paréntesis de textos ajenos incorporados a la propia voz, como sucede -por poner un único ejemplo- en el siguiente poema de Espejo de alinde:

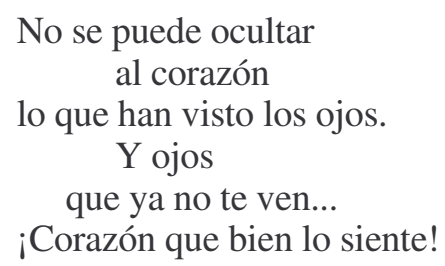


El poema reelabora un dicho popular: "Ojos que no ven, corazón que no siente"; el préstamo aparece muy reelaborado y hay que interpretarlo dentro del contexto amoroso del poema. El préstamo no indica en esta poesía agotamiento creativo, sino estímulo generador de nuevos textos.

\section{Núcleos temáticos}

No es el amor el único motivo de la poesía de Amparo Carballo, pero sí el más persistente. A su lado laten otros en los que el sentimiento amoroso no está ausente, como es el caso de las preocupaciones sociales, que se dieron primordialmente en su primer libro, Tiempos en la misma voz, y sólo muy ocasionalmente en poemarios posteriores. Una poesía centrada en los sentimientos se acerca al yo sujeto y depósito de los mismos, mira hacia el tiempo fugaz o medita sobre su oficio de poeta, sobre las palabras, el poema y la poesía. Raramente los ojos se posan sobre un paisaje, natural o urbano; en las ocasiones en que así sucede, el paisaje acaba siendo referente o imagen del sentimiento o de la situación del sujeto lírico. Son los núcleos temáticos de la poesía de Amparo Carballo.

\section{Isla desierta e inhóspita del yo}

En numerosos poemas el yo enunciador se convierte en objeto del poema. Es la intimidad misma (o la mismidad) la que se convierte en objeto de inquisición poética. Es un yo que aparece en soledad, meditando sobre sí mismo, perplejo tal vez, que, si reafirma algunas convicciones, se interroga sobre su propia identidad: “¿Qué mente, qué alma, / en qué lugar se encuentra / el yo que me dirige?”; “...interrogando espejos / que no saben, que no dicen / quién es yo en realidad" (Aletheia). En cualquier caso, se trata de un yo que busca salidas y aire para los ahogos existenciales. La Poesía, con mayúscula, que "inventa" imágenes y hasta "un dios / hacia quien volverme", puede ser la puerta de salida o el aire que el yo necesita para reconocerse, el lugar de encuentro con uno mismo.

\section{Por ti se tensan mis sentidos}

La poesía de Amparo Carballo expresa básicamente contenidos amorosos, parece resolverse, al fin, en un sueño de amor vertido en palabras. La poesía amorosa viene a ser, en general, un diálogo ficcional con un tú, destinatario ausente y silencioso de los sentimientos íntimos del sujeto lírico: "Vientos favorables impulsan / el velero del verso / en dirección tú: único puerto / única isla habitable / en el gélido mar coti- 


\section{J.E. Martínez Fernández}

diano" (Maleficio de otoño). En el soliloquio que es el poema, más que diálogo, aparecen todos los motivos tradicionales de la poesía amorosa: melancolías y ausencias, recuerdos, deseos, fragilidades del ánimo, soledades y silencios, temores y olvidos, ansiedades, sueños, esperanzas y desengaños, olvidos y promesas, ilusiones, inconstancias y toda una gama de matices sentimentales difíciles de precisar, porque el amor puede sentirse en las manos o como viento huidizo, como ola rumorosa o como poderoso huracán, como algo cercano y alejado a la vez, perseguido por la memoria o por el deseo. Son motivos espigados en la poesía de Amparo Carballo, que puede cantar al amor como fuerza huracanada y ardorosa, que rara vez encuentra reciprocidad, por lo que aboca al desconsuelo; el amor esperanzado origina el bello poema "A veces duerme el corazón", de Maleficio de otoño; el desengaño concibe el amor como mero sueño, como "un poco de viento"; el amor, justificación de la existencia, no es, en el fondo, más que ilusión o ideal inalcanzable, "inaccesible isla de ensueños". De los diferentes motivos temáticos quisiera destacar el entendimiento del amor como invención consoladora, ficción, por lo tanto, palabra, "amor de tinta": "Escrito con agua / guardo un beso entero, / y un sueño de amor inventado / para creerlo" (Aletheia). Me gustaría añadir que en Aletheia la poeta ensaya nuevos tonos y formas renovadas, acercándose a la poesía tradicional ("Ay, no cortes la flor / de la amapola. / No lleves, amor, / su incendio a casa, / que se desarbola") y a la de cancionero ("Apartar alma y corazón quisiera / de los ardores del terrible mal") o adoptando un tono ligero que da al amor y al verso aire de juego: "En todo caso el amor / es eso, / se trata de eso: / un juego de siempre / empezar. / Eso es todo". También en La sombra de las palabras hay hermosos poemas de amor, llenos de delicadeza, como el que transcribo, en el que el oxímoron inicial recibe la explicación subsiguiente:

$$
\begin{aligned}
& \text { Amigo enemigo mío: } \\
& \text { tus labios son de seda, } \\
& \text { tus palabras } \\
& \text { más suaves que el aceite, } \\
& \text { pero tu corazón, } \\
& \text { esa zona de sombra, } \\
& \text { me hace la guerra. }
\end{aligned}
$$

Toda la parte tercera y última del poemario tiene como asunto el tema amoroso, tal como quedó brevemente descrito en las líneas dedicadas al libro en páginas anteriores. 


\section{Apoyada en el quicio del tiempo}

El tiempo no es una mera idea, simple abstracción, sino vivencia, y vivencia que se aferra a las cosas que cambian o desaparecen, a las personas que encanecen y mueren. De ahí el lamento elegíaco, que se cifra en el conocido tópico del ubi sunt?; no es extraño que en la poesía de Amparo Carballo el asidero del tiempo sea la vivencia amorosa: “¿Dónde están las palabras / que ayer anudaron la garganta...?”; “¿Dónde están las caricias / que ayer recorrieron la piel...?" (Maleficio de oto$\tilde{n} o$ ). Una de las imágenes tradicionales del tiempo huidizo es la del agua que fluye, la corriente presurosa. La imagen manriqueña, a fuerza de reiterarse, es tópica también: la muerte acecha con "la inmovilidad / que es el morir"; a Dios se le interroga "por qué la sangre / cabe toda en el mar / que es el morir" (Espejo de alinde); también el Quevedo más hondo asoma en esa confluencia de tiempos que expresa la fugacidad absoluta: "hoy ya es ayer", escribe la poeta en el último libro citado.

En la vivencia humana del tiempo los dos extremos son "la cuna y la sepultura". La niñez se presenta como una mirada de añoranza, ordinariamente, pues es frecuente recordarla como pasado perdido. Se subraya lo que la niñez tuvo de sueño e ilusión, de inocencia, de asombro y descubrimiento; y ese asombro continuo no dependía del tiempo, casi detenido en la percepción infantil, en contraste con la edad adulta, para la cual "los días / no tienen asiento, / son de rápidos vuelos" (Espejo de alinde). En el otro extremo están la vejez y la muerte. Amparo Carballo no suele poetizar el pensamiento de la muerte (renuncia incluso a expresarlo y se reduce a nombrar la palabra, si bien "no me arriesgo / a enfrentarme a ella", La sombra de las palabras), pero sí su desamparo ante los muertos con nombre propio, parientes, amigos y poetas principalmente. En su obra encontramos poemas a la muerte de su padre y a la muerte de Celso Emilio Ferreiro, Bergamín y algunos otros. En relación con el paso del tiempo y su acción destructora, la poesía barroca instaló el tema de las ruinas como campo propicio al desengaño. El tema de las ruinas dicta el poema escrito "Ante el Castillo de los Templarios de Ponferrada" (Espejo de alinde), que, sin embargo, expresa la resistencia al tiempo de las piedras almenadas.

\section{Yo sé que el mar no es un paisaje}

No hay en la obra de Amparo Carballo poemas paisajísticos. Como mucho, elementos del paisaje, escuetos siempre, porque sirven a otras finalidades que la mera descripción o la fruición contemplativa. Esos escasos elementos (el otoño, el mar, la nieve, la plaza...) configu- 


\section{J.E. Martínez Fernández}

ran imágenes o referentes sentimentales. El otoño no es más que melancolía; la nieve disuelta, agua que arrastra las esperanzas, y su afán de solidez, espejo de ansias sin sostén; la plaza desierta bajo el frío de enero es "aguazal del olvido"; y el mar... El mar es una presencia constante en la poesía de Carballo Blanco; en otros poetas ha servido para expresar la naturaleza en su estado elemental, en su infinitud o en su potencia; nuestra escritora no se recrea en su belleza o en su fuerza, ni siquiera en el vaivén de las olas o en el reflejo de las nubes navegando sobre las olas en calma, acaso por seguir el ejemplo paterno: "Mi padre nunca me llevó al mar. / No creía en el mar" (Aletheia). Cuando un poema de Espejo de alinde comienza: "Yo sé que el mar / no es un paisaje", la poeta expresa perfectamente su intuición poética: el mar no es un paisaje, sino un referente sentimental, una imagen metafórica o un símbolo.

\section{No tengo más luz que la luz de la palabra}

Tras el amor, la palabra poética es el otro gran núcleo temático de la obra de Amparo Carballo. En realidad amor y poesía van conexionados, pues el fuego del poema se aviva en "el aire del amor": "Si te tuviera no habría / ya amor; / si no te tuviera ni siquiera / te amaría. / En esta oscilación / de tener y no tener / se engendra la poesía" (Espejo de alinde). El "espacio acotado" que es el poema acoge "su única sustancia: el Amor" (La sombra de las palabras). Al fin, la palabra, la poesía, es la depositaria del amor en cuanto expresión de dudas y certezas, plenitudes y vacíos. La palabra, decíamos, inventaba el amor como consuelo; la palabra se engendra en el amor y a la vez lo inventa. Pero aquí no se trata de divagar en torno a dicho asunto, sino de reflejar la atención de la escritora hacia su instrumento, la palabra, el poema; a veces el poema es una mera efusión sentimental ("Casi todos los días / te quiero y te odio...", Espejo de alinde), pero otras veces es una reflexión sobre el oficio de moldear palabras. Ya en "Como el mar", de Tiempos en la misma voz, se plantean diferentes posibilidades para el poema, tanto en lo referente a su nacimiento y vitalidad ("se nutre de íntimas sustancias, / de nacaradas perlas, / de oscuros abismos"), como a su resultado final, de la posible plenitud al posible vacío. Maleficio de otoño se abre con un poema significativo que expresa las dificultades de la expresión poética: “¿Cómo decir lo indecible? [...] / ¿Cómo abrir las palabras? / ¿Cómo hacer sonar la música / perfecta / que envuelva el abrazo?". La creación poética avanza entre dudas, negaciones, ignorancias, interrogaciones... La palabra debería acoger el sentimiento en toda su plenitud; pero nombrarlo es restringir su fuerza o su pureza: “¿Cómo 
liberar el sentimiento / de la palabra misma que lo nombra?". Un imposible. Sin embargo, para un poeta lo único tangible es la palabra: "No tengo más luz que la luz de la palabra". La palabra puede revelar lo oculto, traducir lo vivido y lograr una perduración que siga alimentando "la rosa de los sueños". La escritora no es ilusa: sabe la fuerza de la palabra, pero ha experimentado sus carencias. Ya líneas atrás indicábamos la precariedad de la poesía enfrentada al sufrimiento del hombre: "No existe poema alguno / capaz de aligerar / las hambres / que hunden los hombros" (Espejo de alinde); en otro poema, éste de La sombra de las palabras, la poeta busca la palabra para "huir inútilmente / del acoso de una muerte sin salida". En "Para el poema...", de Espejo de alinde, la escritora trazará todo un programa particular "para que el poema / sea consistente y cruja": intuir, indagar, revelar..., desde el recuerdo y el amor, que sustentan "la flor de la ilusión"; pero, además, propone un compromiso de comunión con los demás bajo la imagen del pan compartido. El compromiso básico es con el lector, que es quien, finalmente, saboreará (dará sentido) a esa "textura de manjar" que se le ofrece.

\section{Referencias bibliográficas}

A. de A. 1998. "Amparo CARBALLO BLANCO, Maleficio de otoño". El Antoniano, $\mathrm{n}^{\circ}$ 28, La Paz, Bolivia, pp.7-8.

CARBALLO BLANCO, Amparo. 1993. Tiempos en la misma voz. León (Ediciones Clave).

CARBALlO BLANCO, Amparo.1996. Maleficio de otoño. León (Celarayn).

CARBALlO BLANCO, Amparo.1998. Aletheia. Ponferrada.

CARBAllo BLANCO, Amparo.1999. Sin otra luz y guía. Poesía, 193-1998. León (Ediciones del Curueño).

CARBALlO BLANCO, Amparo. 2001. Espejo de alinde. Madrid (Huerga \& Fierro).

CARBALLO BLANCO, Amparo. 2002. La sombra de las palabras. Ponferrada (Ediciones Hontanar).

CARNICER, Ramón. 1993. "Prólogo" a Tiempos en la misma voz, pp.7-8.

CARNICER, Ramón. "Prólogo" a Maleficio de otoño, pp.5-6.

CASTELLANOS, L. 2001. "Las palabras pueden volverse oscuras" (entrevista). El Mundo /La Crónica de León, 28 de mayo.

CRÉMER, Victoriano. 1999. "Prólogo" a Sin otra luz y guía. Poesía, 1993-1998, pp.7-11. 
FIDALGO ROBLEDA, Helena. 1995. "La poesía de Amparo Carballo". Aquiana, Ponferrada, 2 de septiembre, 1995.

FIDALGO ROBLEDA, Helena. "Aletheia. Profesión de fe en la palabra". Aquiana, Ponferrada, Mayo, 1998, p.28.

FIDALGO ROBLEDA, Helena. 1999. "Amparo Carballo Blanco. Sin otra luz y guía". Aquiana, Ponferrada, Agosto, 1999, p.27.

FIDALGO ROBLEDA, Helena. 2001 "Espejo de alinde, Amparo Carballo Blanco". Zurgai, Julio, pp.127-128.

GAMONEDA, Antonio. 1998. "Prólogo" a Aletheia, pp.9-10.

IGLESIAS, Mar. 2001. "La concavidad de la poesía". La Tronera de ierzo 7, 19 de abril, $\mathrm{n}^{\circ} 15$.

MARTÍNEZ, José Enrique. 1995. “Tiempos en la misma voz”. Diario de León (Filandón), 22 de octubre.

MARTÍNEZ, José Enrique. 1996. "Maleficio de otoño". Diario de León (Filandón), 26 de mayo.

MARTÍNEZ, José Enrique. 1998. "Fuego avivado por el aire del amor". Diario de León (Filandón), 26 de abril.

MARTÍNEZ, José Enrique. 1999. “...Sino la que en el corazón ardía”. Diario de León (Filandón), 23 de mayo.

MARTÍNEZ, José Enrique. 2000. "Poesía leonesa última (1975-2000)". Zurgai, diciembre, 24-30.

MARTÍNEZ, José Enrique. 2002. "Un dibujo en el agua”. Diario de León (Filandón), 19 de mayo. 